\title{
Nutritive Value and Sensory Evaluation of Airline Breakfast
}

\author{
Vedavalli Sachithananthan ${ }^{1,2}$, Mohammed Buzgeia ${ }^{2}$, Emberika Khalifa ${ }^{2} \&$ Najwa Abdul Hamid ${ }^{2}$ \\ ${ }^{1}$ Department of Clinical Nutrition, College of Applied Medical Sciences, University of Hail, Hail, Saudi Arabia \\ ${ }^{2} \mathrm{Al}$ Arab Medical University, Benghazi, Libya \\ Correspondence: Vedavalli Sachithananthan, Department of Clinical Nutrition, College of Applied Medical \\ Sciences, University of Hail, Hail, Saudi Arabia. Tel: 966-582-844-654. E-mail: dr_vedavalli@yahoo.com
}

Received: March 30, 2012 Accepted: April 23, 2012 Online Published: October 30, 2012

doi:10.5539/jfr.v1n4p218 URL: http://dx.doi.org/10.5539/jfr.v1n4p218

\begin{abstract}
Purpose/Objectives: This study was conducted to assess the nutritive value of Libyan airline breakfast in comparison with the Recommended Dietary Allowances (RDA) and to conduct sensory evaluation of selected items on board the flights.

Design/Methodology: Food samples were collected from the catering department of Benina International airport, Benghazi, Libya for a period of two months and nutritive value was calculated. A self administered questionnaire prepared on the basis of the Hedonic scale was used for inflight sensory evaluation of selected snacks.

Findings: The results on nutritive value of snacks revealed higher amounts of energy, carbohydrates, saturated fat and sodium in comparison to the RDA when the full day's meal was considered. Micronutrients such as vitamins A, E, C and folic acid fell short of RDA. Sensory evaluation revealed that a majority of the travelers disliked most of the breakfast items except juice.

Practical implications: The airline needs to improve the micronutrient content of snacks, simultaneously reducing the total energy and sodium content and replacing saturated fat to prevent health risks to regular airline passengers. Also palatability need not be compromised in light of safety of food items served.
\end{abstract}

Keywords: airline breakfast, nutritive value, customer satisfaction, sensory evaluation

\section{Introduction}

Airline meals are an essential part of airline travel. In the early days of air travel, food was cooked in the air and passengers sat at dining tables to eat. Now, much food is prepared in the airport catering department, plated, kept warm and served on the plane (www.articeworld org/index.php/airline-meal). During morning flights, a smaller continental style or hot breakfast is served, which may include a miniature box of breakfast cereal, cut fruits, a muffin or pastry or a bagel. Some airlines offer the choice of hot breakfast meals to the passengers who include pancake or eggs, muffins or pastry, fruits and breakfast cereals, coffee or tea and sometimes hot chocolate. (www.en.wikipedia.org/wiki/Airline-meal).

Airlines generally outsource food service to catering companies that specialize in preparing meals for flights. Catering companies place emphasis on the quality and variety of food in order to gain highest customer satisfaction in the four dimensions of taste, eye, smell and content. In airline catering the personnel go further than the regular (HACCP) rules to ensure that the passengers receive an outstanding product (www.corporate-catering Zurich.com /en /services /in flight catering). Due to the high energy, fat and salt content of airline food, airline caterers should aim at providing balanced low energy, low fat and low salt diets while flying (http://www.edition.cnn.com/2005/TRAVEL /06/03/bt.airline.food/index.html).

This study was conducted to assess the nutritive value of Libyan airline breakfast in comparison with the Recommended Dietary Allowances (RDA) and to conduct sensory evaluation of selected items on board the flights.

\section{Methods}

This study was conducted in two stages - Study of the nutritive value of breakfast served by Libyan airlines and evaluation of the sensory characteristics of selected breakfast items. For the study on nutritive value, samples of breakfast items were collected randomly from Libyan airlines catering department. The breakfast items were 
weighed. Coffee and juice were measured using measuring cups. After estimating the amount of the different ingredients in the menu, the food composition tables (Smolin \& Grosvenor, 2003) were used for calculation of the nutritive value.

The nutritive value was calculated separately for each of the different menu items and summed up to get the nutritive value of the breakfast. This was compared with Recommended Dietary Allowances (RDA) for the age group 31-50 years (Food \& Nutrition Board, 2004) under assumption that a majority of the travellers usually belong to this age group. For comparison of energy content of the selected food items, the energy equation for age group 31-50 years was adopted. Also the fat and saturated fat content to meet $30 \%$ and $7 \%$ of the energy requirements according to NCEP guidelines were used as a standard for comparison (NIH, 2002).

The Hedonic Scale, which is a nine point scale was used to assess the sensory characteristics of food items served in the Libyan airlines aircraft with respect to taste, colour, smell and overall acceptability (ASTM, 1968). A structured self administered questionnaire was prepared using the Hedonic Scale for sensory evaluation of selected food items served for breakfast. 220 questionnaires were distributed randomly to passengers travelling from Benghazi to Damascus, Amman and Cairo by the cabin crew and forwarded to the Benghazi airport authorities for collection by the investigators. 200 passengers cooperated and participated in the study and returned the filled up questionnaires.

Data collected were analyzed and presented in the tables. Correlation between sensory characteristics (taste, smell, colour) and overall acceptability of food items served during breakfast were done using Pearsons correlation on SPSS software.

\section{Results}

The nutritive value of breakfast which included white bread, whole fat milk, butter, jam, honey, dry cake, fruit salad and juice and coffee is presented in comparison with RDA in Table 1.

Table 1. Nutritive value of Breakfast served by Libyan airlines in comparison with RDA

\begin{tabular}{|c|c|c|c|}
\hline \multirow{2}{*}{ Nutrients } & \multirow{2}{*}{$\begin{array}{c}\text { Nutritive value of Break } \\
\text { Fast }\end{array}$} & \multicolumn{2}{|c|}{$\begin{array}{c}\% \text { of RDA met by } \\
\text { Break Fast }\end{array}$} \\
\hline & & $\begin{array}{l}\text { \%RDA of* adult } \\
\text { man }\end{array}$ & $\begin{array}{l}\% \text { RDA of } * * \text { adult } \\
\text { woman }\end{array}$ \\
\hline Energy (Kcal) & 680 & $28-40$ (a) & $38-43$ (a) \\
\hline Carbohydrate (g) & 124.8 & 96 & 96 \\
\hline Protein (g) & 18.4 & 30 & 40 \\
\hline Fiber $(\mathrm{g})$ & 8.5 & 20 & 40 \\
\hline Total Fat (g) & 16.3 & $20-30(b)$ & $27-30(b)$ \\
\hline Saturated fat $(\mathrm{g})$ & 7 & $37-60(\mathrm{c})$ & $50-55(c)$ \\
\hline Calcium(mg) & 415 & 40 & 40 \\
\hline Iron (mg) & 4.9 & 60 & 30 \\
\hline Sodium (mg) & 710.6 & 45 & 45 \\
\hline Vitamin A $(\mu \mathrm{g})$ & 76 & 10 & 11 \\
\hline Vitamin C (mg) & 3.1 & 13 & 14 \\
\hline Vitamin E (mg) & 1.15 & 10 & 10 \\
\hline Thiamine (mg) & 1.19 & 100 & 108 \\
\hline Riboflavin (mg) & 0.71 & 75 & 65 \\
\hline Niacin (mg) & 4.76 & 30 & 35 \\
\hline Vitamin B6 (mg) & 0.9 & 70 & 68 \\
\hline Vitamin B12 (mg) & 2.3 & 98 & 99 \\
\hline Folic acid (mg) & 83.3 & 20 & 20 \\
\hline
\end{tabular}

* RDA (recommended dietary allowances) for adult man aged 31-50 years was considered for comparison of the nutritive value of breakfast. Values presented represent percentage of RDA of adult man met by breakfast.

** RDA for adult women aged 31-50 years was considered for comparison of the nutritive value of breakfast. Values presented represent percentage of RDA of adult woman met by breakfast.

(a) Has been computed based on EER (estimated energy requirement) for ages 31- 50 years with reference BMI (Body mass index) (16).

(b) and (c) have been computed based on NCEP (National cholesterol education program) guidelines. 
With respect to percentage of RDA met by breakfast, the carbohydrate, thiamine and vitamin B12 content of breakfast alone met 95-110 percent of the RDA of adult man and woman. The energy, protein, calcium and niacin content of breakfast met 25- 50 percent of the RDA of both adult man and woman. With respect to the content of riboflavin and vitamin B6, breakfast met $65-80 \%$ of the RDA of both sexes. Less than $15 \%$ of the RDA was met for nutrients such as vitamins A, C and $\mathrm{E}$. The fat content of breakfast was $16.3 \mathrm{~g}$ of which almost 43 percent was saturated fat. Saturated fat intake met almost 35-60\% of RDA of both sexes for breakfast alone.

Sensory evaluation of selected breakfast items such as coffee and cake were performed by travellers on board flights travelling from Benghazi to Damascus, Amman and Cairo. The travellers who evaluated the food items for breakfast were distributed according to the type of travelling class and the data is presented in Table 2 .

Table 2. Distribution of travelers undergoing sensory evaluation of breakfast according to type of traveling class

\begin{tabular}{lcc}
\hline \multicolumn{1}{r}{ Traveling class } & No & $\%$ \\
\hline First & 3 & 6 \\
Second & 2 & 4 \\
Touring & 45 & 90 \\
Total & 50 & 100
\end{tabular}

A majority of the travellers who participated in the sensory evaluation of breakfast were seated on the touring class $(90 \%)$. Only $6 \%$ travelled in first class and $4 \%$ travelled in second class. The duration of travel was one hour.

The distribution of travellers according to sensory evaluation of coffee served for breakfast is presented in Table 3 .

Table 3. Distribution of travellers according to sensory evaluation of breakfast items (coffee)

\begin{tabular}{|c|c|c|c|c|c|c|c|c|}
\hline \multirow{3}{*}{ Opinion } & & & & & \multicolumn{4}{|c|}{ Breakfast items(coffee) } \\
\hline & \multicolumn{2}{|c|}{ Taste } & \multicolumn{2}{|c|}{ Smell } & \multicolumn{2}{|c|}{ Colour } & \multicolumn{2}{|c|}{ Overall acceptance } \\
\hline & NO. & $\%$ & NO. & $\%$ & NO. & $\%$ & NO. & $\%$ \\
\hline Like extremely & 2 & 4 & 2 & 4 & 5 & 10 & 5 & 10 \\
\hline Like very much & 2 & 4 & 2 & 4 & 2 & 4 & 2 & 4 \\
\hline Like moderately & 2 & 4 & 2 & 4 & 4 & 8 & 4 & 8 \\
\hline Like slightly & 4 & 8 & 4 & 8 & 8 & 16 & 10 & 20 \\
\hline $\begin{array}{l}\text { Neither like nor } \\
\text { dislike }\end{array}$ & 2 & 4 & 2 & 4 & 10 & 20 & 7 & 14 \\
\hline Dislike slightly & 8 & 16 & 4 & 8 & 1 & 2 & 0 & 0 \\
\hline Dislike moderately & 7 & 14 & 9 & 18 & 1 & 2 & 1 & 2 \\
\hline Dislike very much & 13 & 26 & 18 & 36 & 7 & 14 & 13 & 26 \\
\hline Dislike extremely & 10 & 20 & 7 & 14 & 12 & 24 & 8 & 16 \\
\hline Total & 50 & 100 & 50 & 100 & 50 & 100 & 50 & 100 \\
\hline
\end{tabular}

A majority of the travellers disliked very much the taste (26\%) and smell (36\%) and disliked extremely (24\%) the colour of coffee served for breakfast. With respect to overall acceptability, a majority of the travellers (26\%) stated that they disliked coffee very much. Only $10 \%$ of the travelers have stated that they liked coffee extremely.

The distribution of travellers according to sensory evaluation of cake served for breakfast is presented in Table 4 . 
Table 4. Distribution of travellers according to sensory evaluation of breakfast items (cake)

\begin{tabular}{|c|c|c|c|c|c|c|c|c|}
\hline \multirow{3}{*}{ Opinion } & & & \multicolumn{6}{|c|}{ Breakfast items(cake) } \\
\hline & \multicolumn{2}{|c|}{ Taste } & \multicolumn{2}{|c|}{ Smell } & \multicolumn{2}{|c|}{ Colour } & \multicolumn{2}{|c|}{ Over all acceptance } \\
\hline & NO. & $\%$ & NO. & $\%$ & NO. & $\%$ & NO. & $\%$ \\
\hline Like extremely & 5 & 10 & 6 & 12 & 5 & 10 & 5 & 10 \\
\hline Like very much & 2 & 4 & 2 & 4 & 2 & 4 & 2 & 4 \\
\hline Like moderately & 4 & 8 & 4 & 8 & 5 & 10 & 4 & 8 \\
\hline Like slightly & 9 & 18 & 10 & 20 & 9 & 18 & 10 & 20 \\
\hline $\begin{array}{l}\text { Neither like nor } \\
\text { dislike }\end{array}$ & 8 & 16 & 11 & 22 & 9 & 18 & 7 & 14 \\
\hline Dislike slightly & 1 & 2 & 2 & 4 & 0 & 0 & 0 & 0 \\
\hline $\begin{array}{l}\text { Dislike } \\
\text { moderately }\end{array}$ & 2 & 4 & 2 & 4 & 1 & 2 & 1 & 2 \\
\hline $\begin{array}{l}\text { Dislike very } \\
\text { much }\end{array}$ & 6 & 12 & 4 & 8 & 7 & 14 & 13 & 26 \\
\hline Dislike extremely & 13 & 26 & 9 & 18 & 12 & 24 & 8 & 16 \\
\hline Total & 50 & 100 & 50 & 100 & 50 & 100 & 50 & 100 \\
\hline
\end{tabular}

A majority of the travellers disliked extremely the taste (26\%) and colour (24\%) of cake served for breakfast. However with respect to smell of cake, a majority of the travellers (22\%) have stated that they neither liked nor disliked the smell. Only $10 \%$ of the travellers liked the product extremely with respect to overall acceptability, whereas a majority $(26 \%)$ disliked it very much.

Table 5 depicts the distribution of travellers according to sensory evaluation of juice served for breakfast.

Table 5. Distribution of travellers according to sensory evaluation of breakfast items (Juice)

\begin{tabular}{|c|c|c|c|c|c|c|c|c|}
\hline \multirow{3}{*}{ Opinion } & & & & & \multicolumn{4}{|c|}{ Dinner items (Juice ) } \\
\hline & \multicolumn{2}{|c|}{ Taste } & \multicolumn{2}{|c|}{ Smell } & \multicolumn{2}{|c|}{ Colour } & \multicolumn{2}{|c|}{ Over all acceptance } \\
\hline & NO. & $\%$ & NO. & $\%$ & NO. & $\%$ & NO. & $\%$ \\
\hline Like extremely & 11 & 22 & 10 & 20 & 0 & 0 & 0 & 0 \\
\hline Like very much & 0 & 0 & 0 & 0 & 13 & 26 & 13 & 26 \\
\hline Like moderately & 6 & 12 & 6 & 12 & 18 & 36 & 19 & 38 \\
\hline Like slightly & 14 & 28 & 15 & 30 & 0 & 0 & 0 & 0 \\
\hline Neither like nor dislike & 8 & 16 & 8 & 16 & 10 & 20 & 10 & 20 \\
\hline Dislike slightly & 0 & 0 & 0 & 0 & 0 & 0 & 0 & 0 \\
\hline Dislike moderately & 0 & 0 & 0 & 0 & 0 & 0 & 0 & 0 \\
\hline Dislike very much & 5 & 10 & 5 & 10 & 9 & 18 & 18 & 16 \\
\hline Dislike extremely & 6 & 12 & 6 & 12 & 0 & 0 & 0 & 0 \\
\hline Total & 50 & 100 & 50 & 100 & 50 & 100 & 50 & 100 \\
\hline
\end{tabular}

With respect to juice served for breakfast, a majority of the travellers liked slightly the taste (28\%) and smell (30\%); whereas $(36 \%)$ liked moderately the colour of the product. With respect to overall acceptability $38 \%$ of the travellers liked the juice moderately and a smaller percentage of them (16\%) disliked it very much.

The data on correlation between sensory characteristics (taste, smell, colour) and overall acceptability of food items served during breakfast is presented in Table 6 . 
Table 6. Correlation between sensory characteristics and overall acceptability of food items served during breakfast

\begin{tabular}{cc}
\hline Food items & Correlation coefficient $\mathrm{r}$ \\
\hline Coffee & 0.96 \\
Taste & 0.98 \\
Smell & 0.98 \\
Colour & \\
Cake & 0.98 \\
Taste & 0.97 \\
Smell & 0.97 \\
Colour & \\
Juice & 0.86 \\
Taste & 0.88 \\
Smell & 0.90 \\
Colour &
\end{tabular}

$r$ is calculated using Pearson's correlation $p<0.05$.

A strong correlation existed between sensory characteristics (such as taste, smell, colour) and overall acceptability of coffee, cake and juice served during breakfast.

\section{Discussion}

Analysis of the data on nutritive value of Libyan airline breakfast showed that except for carbohydrates, the energy, protein, total fat and saturated fat content of breakfast, fell short of the RDA. With respect to micronutrient content, all nutrients fell short of the RDA, except thiamin and vitamin B12. It can be argued that when the whole day's meal is considered, the macronutrients such as energy, carbohydrate, protein and saturated fat will exceed the RDA and micronutrients such as vitamins A, C, E and folic acid will fall short of the RDA of both sexes. With respect to sodium, the day's RDA will be well exceeded. Hence macronutrients especially energy, carbohydrates and saturated fat and micronutrients such as sodium, need to be decreased in airline menus. Studies on airline meals with respect to meals served on United States (http://www.edition.cnn.com/2005/TRAVEL/06/03/bt.airline.food/index.html) and German airlines (Grammatikopoulou et al., 2007) have shown that the energy, fat, saturated fat (saturated fat content contributing to $50 \%$ of the total fat content) and sodium contents were very high and this finding supports the results of the present study.

With respect to sensory evaluation of breakfast items, except for juice which was liked moderately, all the other items were disliked by a majority of the travelers. Though safety is of paramount importance with respect to airline meals, taste and appeal of the food need not be compromised (Grammatikopoulou et al., 2007).

\section{Conclusion}

The results of the present study prods one to conclude that energy, saturated fat and sodium content when projected for the full day's meal, especially when travelling on a long duration flight needs serious consideration and these nutrients have to be reduced in airline food. Micronutrient increments in airline food especially with respect to vitamins are the need of the hour. With respect to sensory evaluation, the results of the study are not in favor of the Libyan airline foods, since the foods served are not to the satisfaction or appeal of the passengers. This is another point of consideration for this airline.

\section{References}

ASTM. (1968). Manual on sensory testing methods, No. 434. American society for testing materials, Philadephia.

Contributor. (2005). The lowdown on in-flight meals. Retrieved from http://www.edition.cnn.com/2005/TRAVEL /06/03/bt.airline.food/index.html

Food and Nutrition Board. (2004). Dietary Reference Intakes: Recommended intakes for individuals. Food and Nutrition Board, Institute of Medicine, National Academy of Sciences, Washington, DC. 
Grammatikopoulou, M. G., Zakas, A., Papadopoulou, S. K., \& Panayiotoglou, A. (2007). The nutritional value and health issues of in-flight meals offered by Greek airlines: a preliminary study. Journal of Foodservice, 18(3), 87-92. http://dx.doi.org/10.1111/j.1745-4506.2007.00054.x

National Institute of Health. (2002). Third report of the National Cholesterol Education Program (NCEP) Expert Panel on Detection, Evaluation, and Treatment of High Blood Cholesterol in Adults (Adult Treatment Panel III): Final Report. US Department of Health and Human Services; Public Health Service; National Institutes of Health; National Heart, Lung, and Blood Institute, NIH Publication No. 02-5215.

Smolin, L. A., \& Grosvenor, M. B. (2003). Nutrition: Science and Applications, $4^{\text {th }}$ edition. Wiley and sons, A-1-A-10.

www.articeworld.org/index.php/Airline-meal

www.corporate-catering Zurich.com /en /services /in flight catering

www.en.wikipedia.org/wiki/Airline-meal 